\title{
Hypermedia on peripheral venipuncture: effectiveness in teaching nursing students
}

Hipermídia sobre punção venosa periférica: efetividade no ensino de acadêmicos de enfermagem

Hipermedia sobre punción venosa periférica: la efectividad en la enseñanza de académicos de enfermería

\section{Natasha Marques Frota', Nelson Miguel Galindo Neto", Lívia Moreira Barros"II, Francisco Gilberto Fernandes Pereiralv , Geórgia Alcântara Alencar Melov ${ }^{\mathrm{v}}$, Joselany Áfio Caetanov}

' Universidade da Integração Internacional da Lusofonia Afro-Brasileira. Acarape, Ceará, Brazil.

"Instituto Federal de Educação, Ciência e Tecnologia de Pernambuco. Pesqueira, Pernambuco, Brazil.

III Universidade Estadual Vale do Acaraú. Sobral, Ceará, Brazil.

Iv Universidade Federal do Piauí. Teresina, Piauí, Brazil.

${ }^{v}$ Universidade Federal do Ceará. Fortaleza, Ceará, Brazil.

How to cite this article:

Frota NM, Galindo Neto NM, Barros LM, Pereira FGF, Melo GAA, Caetano JA. Hypermedia on peripheral venipuncture: effectiveness in teaching nursing students. Rev Bras Enferm [Internet]. 2018;71(6):2983-9.

DOI: http://dx.doi.org/10.1590/0034-7167-2017-0205

\section{Submission: 03-13-2017 Approval: 04-26-2018}

\section{ABSTRACT}

Objective: To assess the effectiveness of an educational hypermedia in the knowledge of Nursing academics on peripheral venipuncture. Method: Quasi-experimental study with pre and post-test design. Results: The mean number of right answers of the 73 individuals who participated in the study, in the pre-test, was 7.7 (DP $=1.05$ ), and 8.3 in the post-test $(\mathrm{DP}=0.74)$. The comparation of pre and post hypermedia mean number of right answers showed significant difference $(p<0.001)$. Conclusion: Hypermedia is a strategy that increases knowledge and is feasible in the teaching-learning process, being useful as a support tool for teachers and for the development of undergraduate Nursing students.

Descriptors: Nursing; Students, Nursing; Education; Educational Technology; Catheterization, Peripheral.

\section{RESUMO}

Objetivo: Avaliar a efetividade de uma hipermídia educativa no conhecimento de acadêmicos de enfermagem acerca da punção venosa periférica. Método: Estudo quase-experimental com desenho pré e pós-teste. Resultados: A média de acertos dos 73 indivíduos participantes do estudo, no pré-teste, foi de 7,7 ( $D P=1,05)$, e 8,3 no pós-teste ( $\mathrm{DP}=0,74)$. A comparação nas médias de acertos pré e pós hipermídia apresentou diferença significativa $(p<0,001)$. Conclusão: A hipermídia é uma estratégia que aumenta o conhecimento e é viável no processo ensino-aprendizagem, sendo útil como ferramenta de apoio para os professores e para o desenvolvimento de estudantes de graduação em enfermagem.

Descritores: Enfermagem; Alunos de Enfermagem; Educação; Tecnologia Educacional; Cateterismo Periférico.

\section{RESUMEN}

Objetivo: Evaluar la efectividad de una hipermedia educativa en el conocimiento de académicos de enfermería acerca de la punción venosa periférica. Método: Estudio casi-experimental con diseño pre y pos prueba. Resultados: El promedio de aciertos de los 73 individuos participantes del estudio, en el pre prueba, ha sido de $7,7(\mathrm{DP}=1,05)$, y 8,3 en el pos prueba $(\mathrm{DP}=0,74)$. La comparación en los promedios de aciertos pre y pos hipermedia ha presentado diferencia significativa $(p<0,001)$. Conclusión: La hipermedia es una estrategia que incrementa el conocimiento y es viable en el proceso enseñanza-aprendizaje, siendo útil como herramienta de apoyo para los profesores y para el desarrollo de los estudiantes de graduación en enfermería. Descriptores: Enfermería; Alumnos de Enfermería; Educación; Tecnología Educacional; Cateterismo Periférico. 


\section{INTRODUCTION}

Venipuncture is one of the most common procedures in healthcare and is performed to facilitate the injection of liquids in the intravascular lumen. It occurs in more than $80 \%$ of patients in hospitals in Australia and Spain, where $95 \%$ of the accesses are peripherical ${ }^{(1-3)}$.

To fail in the procedure raises the probability of complications and makes is necessary to insert needled devices multiple times, increasing anxiety and suffering, and committing the trust of the patient and their family members in the nursing staff. Thus, nursing professionals must be prepared to perform the procedure correctly and safely ${ }^{(4)}$, which runs through the effectiveness of the teachinglearning process of the peripheral venipuncture (PVP) during training.

The relevance of teaching this topic has influenced the search for pedagogical strategies that facilitate the apprehension of knowledge and obtaining of skills and abilities. Given this context, the use of technologies as didactic tools in Nursing education is intensified to meet the demands of technological incorporation in health practices ${ }^{(5)}$.

Among the several options of teaching technologies, hypermedia is feasible and pertinent, since it allows to represent reality in controlled and safe conditions, and can be used in education and distant training(6).

When considering that viability is not the only criterion to use a technology, scientific evidences are necessary on its effectiveness to justify the choice of educational hypermedia as a resource for teaching. Studies on the impact of digital technologies in Nursing education and on its use in public higher education institutions are shy ${ }^{(7)}$, therefore, the scientific investigation on the use of educational technologies in this teaching area and on contents inherent to professional practice, becomes relevant.

The use of hypermedia as teaching technology must be added to meaningful learning, subsiding education for the nursing student. In the educational context of meaningful learning, the academic is based in a humanistic view, emphasizing the affective and relational learning aspects, such as acquisition and consolidation of knowledge. Given this perspective, adopting technologies favors the teacher-student interaction and contributes in the cognitive processes of professional practice.

\section{OBJECTIVE}

To assess the effectiveness of an educational hypermedia in the knowledge of Nursing academics regarding PVP.

\section{METHOD}

\section{Ethical aspects}

The research project was approved by the Ethics Committee of the Federal University of Ceará, and the research was conducted according to Resolution no. 466/12 of the National Health Council.

\section{Design, location and period}

This is a quasi-experimental study, in which each subject was their own control ${ }^{(8)}$, performed from October 2014 to November 2015, in a public university in Fortaleza, Ceará.

\section{Population or sample: inclusion and exclusion criteria}

The study population was composed of Nursing academics of a public university. Convenience sampling was used, and the inclusion criteria were: to be regularly enrolled in the discipline Nursing in the Adult Care Process II, of the sixth semester in Nursing graduation; and be able to access the virtual learning environment (VLE) where the hypermedia was available. The criterion of being enrolled in the sixth semester is justified as a choice criterion since it is the moment in the course where the students have their first contact with the hospital environment, with the opportunity to perform PVP in real patients instead of mannequins in the skill laboratory.

The exclusion criterion was to have participated in courses or trainings related to PVP and, for study discontinuity, we adopted the unavailability of answering the questionnaire fifteen days after the intervention (post-test). Over the three school semesters of data collection, the classes that were in their sixth semester were invited to participate in the study. Each class had from 35 to 40 students, totaling 105 participants. Of these, 73 fit the established criteria and were included in the sample.

\section{Study protocol}

The instrument used was build based in the Infusion Nurses Society. It consisted of thirty objective questions, classified according to the Item Response Theory. The questions approached subtopics on the procedure, with the following distribution: anatomy, materials used, choice of the catheter and special recommendations (regarding puncture in limbs with fistula, solutions used, use of gauze and presence of "ballerina veins" - a term coined by Ignácio de Loyola Brandão, meaning a vein that moves subcutaneously by itself, dancing) were approached in four questions each; the complications of the procedure regarding the use of the tourniquet were approached in three questions; two questions were destined to the correct selection of the vein to be punctured; one approached procedure contamination; and the last referred to the identification of the access after it was placed. The referred instrument was assessed by three judges (nurses with at least three years of hospital experience) and adjusted according to their suggestions.

The referential of the Ausubel's Meaningful Learning Theory was used, which deals with a humanistic view by considering issues related to seizing, organizing and consolidating knowledge. According to this referential, meaningful learning occurs when potentially significant content is presented logically and coherently, allowing its assimilation to the previous cognitive structure of the learner ${ }^{(9)}$.

Students' data, obtained in the classroom, were used to register them in the virtual platform to access the hypermedia. In the nursing laboratory, the pre-test was applied for thirty minutes and, afterwards, each student used, individually, the educational hypermedia for approximately one hour.

It should be noticed that the hypermedia approaches several aspects regarding PVP procedures, such as venous network anatomy, types of catheter, procedure stages, possible complications and nursing care. This content is shown in the following modules: Module 1 - Introduction to PVP; Module 2 - Venous network anatomy; Module 3 - PVP procedure; Module 
4 - Local and systemic PVP complications; Module 5 - PVP in special patients; and Module 6 - Nonconformity PVP actions. To contemplate the mentioned contents, the hypermedia offered didactic resources such as videos, pictures, hypertexts, hyperlinks and exercises.

After fifteen days using the educational technology, the posttest was applied in the classroom, which lasted 30 minutes.

\section{Analysis of results and statistics}

Data were tabulated in Excel 2007 with double entry. The analysis occurred in the Statistical Package for the Social Sciences (SPSS), version 20.0. Descriptive statistic (mean and standard deviation) was used for the variables regarding to the characterization of the academics. The normality of the means was checked through the Kolmogorov-Smirnov test and the paired T test was used to assess the means of the questions before and after the hypermedia. A significance level of $5 \%$ was adopted.

\section{RESULTS}

Of the 73 study participants, 67 were women (91.8\%), the minimum age was 20 years and the maximum was 32 , and the mean was $23(\mathrm{DP}=2.81)$.

The means of the students showed normal distribution in the pre and post-test, as observed in Table 1.

Considering that the questions had different weights, according to the Item Response Theory, the weighted mean of right answers in the pre-test was of $7.7(\mathrm{DP}=1.05)$ and of 8.3 in the post-test (DP $=0.74)$. The comparison of the mean number of right answers pre and post-hypermedia, using the T test, showed significant difference $(p<0.001)$, therefore, the increase of 0.6 in the mean was statistically significant.

The difference of the mean number of right answers before and after using the hypermedia had a relation with the percentage of right answers by subtopics. Questions about identifying the venous access after its placement and on the use of tourniquet had more than $19 \%$ of increase in the right answer index, while questions about procedure complications presented the smallest percentage of improvement $(6 \%)$ in the post-test. Table 2 shows the distribution of right answers in the pre and post-test, according to the subtopics of the questions.

\section{DISCUSSION}

During graduation, Nursing academics should dominate several practical skills related to patient care, ensuring the acquisition of competencies expected when they complete the course $^{(10)}$. PVP is an essential procedure in patient care, since it provides fast access for hydration and administration of drugs, especially in emergency situations ${ }^{(10-11)}$.

Three prerequisites must be met so that learning about venipuncture is significant. (1) previous knowledge (also known as subsumer), which can be represented by images, symbols or concepts present in the cognitive structure, allowing the connection with new information; (2) academic's willingness to learn, since, if this individual wants to memorize the content taught literally, learning will be mechanic; and (3) offering new knowledge in didactic materials, organized in a logical, sequential way and psychologically significant $t^{(9)}$.

It is known that the PVP procedure is performed, most of the time, by the nursing staff, requiring knowledge and adequate skills to prevent complications and ensure patient safety ${ }^{(12)}$. Such fact may represent the motivational factor to learn the procedure, since, in internship activities during graduation, students have the opportunity to perform their first puncture.

However, for this to be possible, in addition to dexterity to apply the technique, nursing academics must have scientific knowledge on the procedure and critical thinking to clinically

Table 1 - Score obtained in the pre and post-test of the use of hypermedia, Fortaleza, Ceará, Brazil, 2016

\begin{tabular}{llccccccc}
\hline \multirow{2}{*}{ Variable } & & Minimum & Maximum & Mean & $\begin{array}{c}\text { Error of the } \\
\text { mean }\end{array}$ & Standard Deviation & $\boldsymbol{p}$ value* \\
\hline \multirow{2}{*}{ Hypermedia } & Pre & 5.2 & 9.8 & 7.7 & 0.12 & 1.05 & 0.508 \\
& Post & 6.3 & 9.7 & 8.3 & 0.09 & 0.74 & 0.668 \\
\hline
\end{tabular}

Note $-*$ Kolmogorov-Smirnov test

Table 2 - Pre and post-test right answers, according to the subtopics of the questions, Fortaleza, Ceará, Brazil, 2016

\begin{tabular}{lccc}
\hline & & Percentage of right answers & Difference \\
\cline { 2 - 4 } Subtopics of the questions & Pretest & Post-test & 14.9 \\
\hline Venous Anatomy & 57.1 & 72.1 & 14.0 \\
Material for the procedure & 75.6 & 89.7 & 17.9 \\
Contamination & 68.4 & 76.7 & 17.1 \\
Selection of the vein to be punctured & 59.6 & 91.7 & 19.1 \\
Identification of the access & 72.6 & 84.0 & 19.6 \\
Use of tourniquet & 64.3 & 83.2 & 16.1 \\
Choice of catheter & 67.1 & 79.1 & 11.9 \\
Recommendations & 67.1 & 90.4 & 6.0
\end{tabular}


approach the patient, pointing to the relevance of educational technologies that contribute to the fast and replicable dissemination of information on the topic.

In the constructivist theoretical line, we emphasize that students build and assume the responsibilities for their own learning. In this perspective, learning results are based on the skills that the student must know and $\mathrm{do}^{(10)}$. Thus, the educational hypermedia on PVP addresses theoretical concepts of constructivism by allowing the student to be responsible for their learning process, because it is an asynchronous and teaching modality, accessible in several places, allowing students to choose the adequate moment and how fast they study. However, this is limited to the acquisition of cognitive skills, which makes it necessary to perform laboratory activities to develop practical skills.

Patients who undergo PVP may feel anxious before and after the procedure is performed ${ }^{(13)}$, which can disrupt the development of the nursing student during venipuncture. In addition, individuals with difficult venous access may demand a large number of puncture attempts, which may be uncomfortable for the patient and frustrating for the professional ${ }^{(14)}$. Such facts corroborate with the importance of quality when teaching venipuncture for nursing academics, since, faced with situations of difficult puncture or the non-cooperation of the patient, the greater is the scientific knowledge and technical skills on the procedure, the greater will be the success rate to obtain intravascular access on the first attempt, reducing, thus, the discomfort caused to the patient ${ }^{(1,10)}$.

To assist the professional to perform PVP, there are several available technologies, such as ultrasonography, which helps to see the venous network, decreases the number of puncture attempts and complication rates, increasing the patient's satisfaction with the received care ${ }^{(15)}$. However, it is worth mentioning that the use of any hard technology, such as ultrasound equipment, does not dismiss the need of a theoretical framework, such as anatomy and physiology, indications and contraindications inherent to the procedure and the correct use of materials that promote professional and patient safety, for performing the PVP.

According to Ausubel, it is important to explore students' previous knowledge, since learning is only significant when there is a connection of already existing knowledge in the cognitive structure with new knowledge ${ }^{(9)}$. In the context of venipuncture, basic notions of anatomy and physiology of the venous network, antisepsis and the use of individual protective equipment can be important mentions regarding subsumers. Therefore, the relevance of the hypermedia to contemplate such information in the contents about PVP is observed.

In matters regarding venous anatomy and selecting the vein to be punctured, the increase in the percentage of right answers between the pre and post-test was observed, from $57.1 \%$ to $72.1 \%$ and from $59.6 \%$ to $76.7 \%$, respectively. Peripheral venous catheters are most commonly inserted in the cephalic and basilic veins of the forearm or in the metacarpal vein in the hand ${ }^{(16)}$. However, to select the vein to be punctured, a few criteria must be evaluated, according to a study conducted in Italy, with results pointing that visibility, palpation, tortuosity, caliber and frailty are factors that hinder the PVP and that demand evaluation from the professional that performs the procedure ${ }^{(14)}$.

The PVP attempts that are not successful reach $25 \%$ in individuals with difficult venous access ${ }^{(17)}$. Failure to perform the venipuncture may be associated to several factors, such as the patient's age and comorbidities, professional experience and catheter caliber ${ }^{(13-14)}$. The wrong choice of vein to puncture interferes in the success to obtain the access and in its loss, in addition to being associated to possible complications related to the procedure ${ }^{(11)}$.

The puncture site depends on the type of solution to be infused, on the vein condition, patient's conditions (age, comorbidities and preferences), on the duration of therapy and on the available materials in the institution ${ }^{(18)}$. Furthermore, proper positioning of the limb and the use of tourniquet are cares that increase the chances of success of PVP in the first attempt.

Regarding the knowledge of academics on the use of tourniquet, there was an increase of $19.6 \%$ of right answers after the use of the hypermedia. Such finding is relevant, since the tourniquet allows vessel inspection and palpation of the peripheral vein ${ }^{(19)}$, which are essential for successfully obtain venous access.

The questions regarding procedure materials also had more right answers, from $75.6 \%$ in the pre-test, to $89.7 \%$ in the post-test. Concerning the selection of materials for PVP, a study analyzed the care performed by nursing professionals during the puncture of peripherical venous access identified that nurses use cotton, alcohol, garrote, adhesive tape, extensor, syringe with saline solution or distilled water, kidney tray and gloves ${ }^{(18)}$.

The use of gloves by the nursing professors was studied in another research, which analyzed videos on PVP available on YouTube, with results that point out the use of gloves in $86.41 \%$ of the videos. The use of gloves is mandatory for the professional's individual protection from biological agents and for patient safety ${ }^{(20)}$. In order for nursing professionals to use gloves during PVP, it is pertinent to make them aware since graduation, in front of the influence of training in professional performance.

Regarding access identification, the frequency of right answers increased from $72.6 \%$ in the pretest to $91.7 \%$ in the post-test, showing the effectiveness of the hypermedia for cognitive academic gain about care in venipuncture. Information such as date, caliber of the catheter and name of the professional who performed the puncture must be recorded in the venous access fixation, since it is a safety measure that allows any professional to access the data from the device to provide care to the patient or to change the access ${ }^{(14)}$. Furthermore, the correct identification of the intravenous device corroborates with the World Alliance for Patient Safety, of the World Health Organization, and with the National Patient Safety Program, of the Ministry of Health, by contributing to information sharing and to the effective team communication ${ }^{(21-22)}$.

It was noted that questions regarding contamination and complications had more frequency of right answers in the post-test. The peripherical venous catheter is inserted into the skin of the patient, which acts as a protective barrier against microorganisms ${ }^{(16)}$. The barrier rupture allows the occurrence of infections, caused, mainly, by resident microbiota, and may 
result in the emergence of local or systemic infections ${ }^{(18)}$.

The presence of the peripherical venous catheter exposes the patient to the risk of complications such as catheter occlusion, hematoma, infections, infiltration and phlebitis, which can be associated to insufficient knowledge of the nursing staff in the implementing and managing the venipuncture ${ }^{(10-11)}$. Phlebitis is one of the most frequent complications, with incidence of up to $70 \%$ among patients, causing pain, sensitivity to palpitation, erythema, swelling and redness at the insertion site, being associated to the length of stay, material and size of the catheter, and type of administered infusion ${ }^{(11,17)}$.

A randomized clinical trial, which analyzed complications from the use of peripherical venous catheter in adults, identified that the main factors associated to development of the phlebitis were access caliber (20G), puncture in the upper left limb, forearm region and dwelling time of 72 hours or more $^{(23)}$. It is observed that such factors associated to phlebitis are directly related with contents addressed in the hypermedia, such as the correct selection of the vein to be punctured and the identification of the access, which enables the exchange of the intravenous device before the 72 hours.

The technical-scientific knowledge of the nursing staff on intravenous therapy ensures the effectiveness of the treatment and the quality of the provided care, and knowledge on care practices based on scientific evidences is essential (21). By analyzing the complexity and the multiple knowledge so that the PVP is performed with caution, the relevance of scientific investment in the development and assessment of educational technologies on the topic is observed.

One of the main obstacles of meaningful learning is the absence of previous and hierarchical organization of the learner's knowledge, hindering the connection among the subsumers and the new presented information ${ }^{(9)}$. Therefore, it should be noted that the hypermedia is structured in five sequential modules with systematic, clear and objective content, which contributes to the learning process.

The use of chats, forums and complementary activities with suggestion of article reading and critical reflection on the content approached in each hypermedia module allows the teacher to assume a position of facilitator of the learning process through tutoring, questioning key aspects in the apprehension of necessary knowledge for performing the PVP effectively and safely.

Other resources, such as videos, photos, hypertexts and animations, favor the interactivity of the nursing student with the available content, make this teaching method dynamic, attractive and playful, and stimulate the metacognition process, such as perception of relevant contents, memorizing information and formation of critical-reflexive reasoning, contributing to the learner's cognitive gains. In addition, the possibility to view the step-by-step of a puncture through the video may enhance the student's attitude to seek new knowledge when accessing the hypermedia, contemplating, thus, one of the fundamental preconditions for the effectiveness of meaningful learning, which is the academic's will to learn.

Given this context, the teaching and learning process implies in the co-responsibility of the professor and of the academic. The professor should be theoretically subsidized to contribute with the construction of knowledge, by considering that the student has previous knowledge and the nature of the knowledge to be taught, in addition to having potentially meaningful teaching material. Therefore, the academic must actively seek knowledges taught, interpret and relate them with the knowledge they already have ${ }^{(9)}$.

It is believed that the use of hypermedia shows important contributions in the teaching process of venipuncture, given that it favors the enrichment of the nursing academic's cognitive structure by allowing the continuous access to information from the virtual environment, making this moment of teaching asynchronous. When learning is meaningful, knowledge is retained through the metacognition process, being remembered for longer.

In this perspective, the theoretical basis of meaningful learning in the distance learning process, with the use of VLE as hypermedia, expands the chances of learning effectiveness when considering the association between the information preexisting in the cognitive structure and the emergence of new concepts. We emphasize the importance of improving nursing education from innovative methodologies that allow the acquisition of knowledge, improving the cognitive performance of academics.

\section{Limitations of the study}

The limitation of this study is that the investigation occurred only with the use of Information and Communications Technology, such as hypermedia, preventing the comparison of the findings regarding meaningful learning with access to the virtual environment or with other types of educational technologies, such as printed material, and the combination of these materials with active technologies that allow the questioning of the topic in the classroom, such as flipped classroom and team-based learning.

\section{Contributions to the fields of nursing, health, or public policy}

The findings shown contribute with the dissemination of the effectiveness of educational technology, so that it is used as a pedagogical resource by professors and researches in teaching activities, research and extension. Furthermore, it contributes to strengthening the state of the art about the use of this kind of technology to teach venipuncture, favoring the theoretical process of the nursing student to perform the procedure, allowing, thus, better nursing practices in the care of the population.

\section{CONCLUSION}

With the application of the pre and post-test, it was possible to assimilate the content proposed by the hypermedia, from the increase in right answers, especially those on contamination during the procedure, selection of the adequate vein, identification of the access and use of the tourniquet, allowing to infer that there was a cognitive gain on the topic, and, consequently, meaningful learning.

The use of educational technologies in nursing teaching is already a reality in several universities. It is important that the inclusion of this teaching modality is encouraged in higher education institutions and that students are motivated to assume an active role in the teaching-learning process. It is worth 
mentioning that the hypermedia can be used in distance education training, favoring the continuous education of the nursing staff.

We suggest that studies should be performed to investigate the impact of the hypermedia in the development of practical skills in venipuncture. Furthermore, we recommend the investigation of its effectiveness in other nursing education institutions, private and of technical level. It is worth pointing out that studies that aim the apprehension of knowledge after one of three months, in order to verify the effectiveness of the educational hypermedia in long-term learning, are also necessary.

\section{REFERENCES}

1. New KA, Webster J, Marsh NM, Hewer B. Intravascular device use, management documentation and complications: a point prevalence survey. Aust Health Rev[Internet]. 2014[cited 2017 Jan 10];38(3):345-9. Available from: http://www.publish.csiro.au/AH/AH13111

2. Fernández-Ruiz M, Carretero A, Díaz D, Fuentes C, Gonzáles Jl, García-Reyne A, et al. Hospital-wide survey of the adequacy in the number of vascular catheters and catheter lumens. J Hosp Med[Internet]. 2014[cited 2017 Jan 10];9(1):35-41. Available from: https://www.ncbi.nlm.nih.gov/pubmed/24323802

3. González López JL, Arribi Vilela A, Fernández del Palacio E, Olivares Corral J, Benedicto Martí C, Herrera Portal P. Indwell times, complications and costs of open vs closed safety peripheral intravenous catheters: a randomized study. J Hosp Infect[Internet]. 2014[cited 2017 Jan 10];86(2):117-26. Available from: http://www.journalofhospitalinfection.com/article/S0195-6701(13)00382-4/pdf

4. Oliveira AKA, Vasconcelos QLDAQ, Melo GSM, Melo MDM, Costa IKF, Torres GV. Instrument validation for peripheral venous puncture with over-the-needle catheter. Rev Rene[Internet]. 2015[cited 2018 Aug 20];16(2):176-84. Available from: http://www. periodicos.ufc.br/rene/article/view/2702/2087

5. Holanda VR, Pinheiro AKB. Comparison of learning strategies in face-to-face and online courses on sexually transmitted diseases. Texto Contexto Enferm[Internet]. 2015[cited 2017 Jan 10];24(2):530-8. Available from: http://www.scielo.br/pdf/tce/v24n2/01040707-tce-24-02-00530.pdf

6. Matos JC, Lima RRS, Nakata CRG, Castro AF, Guimarães HC, Silva AR. The distance education in teaching and nursing practice: integrative review. Rev Enferm UFPE[Internet]. 2016[cited 2017 Jan 10];10(7):2656-68. Available from: https://periodicos.ufpe.br/ revistas/revistaenfermagem/article/view/11327/13022

7. Holanda VR, Pinheiro AKB, Fernandes AFC, Holanda ER, Souza MA, Santos SMJ. Análise da produção científica nacional sobre a utilização de tecnologias digitais na formação de enfermeiros. Rev Eletrôn Enferm[Internet]. 2013[cited 2016 Aug 7];15(4):106877. Available from: http://revistas.ufg.br/fen/article/view/22448/15753

8. Polit DF, Beck CT, Hungler BP. Fundamentos de pesquisa em enfermagem: métodos, avaliação e utilização. 7th ed. Porto Alegre: Artmed; 2011. p. 406-26.

9. Moreira MA, Masini EFS. Aprendizagem significativa: a teoria de David Ausubel. São Paulo: Moraes; 1982.

10. Ahlin C, Klang-Söderkvist B, Johansson E, Björkholm M, Löfmark A. Assessing nursing students' knowledge and skills in performing venipuncture and inserting peripheral venous catheters. Nurse Educ Pract[Internet]. 2017[cited 2017 Jan 10];23:8-14. Available from: https://www.ncbi.nlm.nih.gov/pubmed/28171853

11. Tan YH, Tai WL, Sim C, Ng HL. Optimising peripheral venous catheter usage in the general inpatient ward: a prospective observational study. J Clin Nurs[Internet]. 2017[cited 2017 Jan 10];26(1-2):133-9. Available from: https://www.ncbi.nlm.nih.gov/pubmed/27325580

12. Cicolini G, Simonetti V, Comparcini D, Labeau S, Blot S, Pelusi G, et al. Nurses' knowledge of evidence-based guidelines on the prevention of peripheral venous catheter-related infections: a multicentre survey. J Clin Nurs[Internet]. 2013 [cited 2017 Jan 10];23(17-8):2578-88. Available from: https://www.ncbi.nlm.nih.gov/pubmed/24354398

13. Salleras-Duran L, Fuentes-Pumarola C. Ultrasound-guided peripheral catheterization. Enferm Clin[Internet]. 2016 [cited 2017 Jan 10];26(5):298-306. Available from: https://www.ncbi.nlm.nih.gov/pubmed/26051396

14. Piredda M, Biagioli V, Barrella B, Carpisassi I, Ghinelli R, Giannarelli D, et al. Factors affecting difficult peripheral intravenous cannulation in adults: a prospective observational study. J Clin Nurs[Internet]. 2016[cited 2017 Jan 10];6(7-8):1074-84. Available from: https://www.ncbi.nlm.nih.gov/pubmed/27324945

15. Danski MTR, Oliveira AM, Meier MJ, Pedrolo E. Effectiveness of ultrasonography-guided peripheral venous access: an integrative review. Enferm Glob[Internet]. 2016[cited 2017 Jan 10];15(44):354-67. Available from: http://scielo.isciii.es/pdf/eg/v15n44/ en_revisiones2.pdf

16. Marsh N, Webster J, Mihala G, Rickard CM. Devices and dressings to secure peripheral venous catheters: a cochrane systematic review and meta-analysis. Int J Nurs Stud[Internet]. 2017[cited 2017 Jan 10];67:12-9. Available from: https://www.ncbi.nlm.nih. gov/pubmed/27889585

17. Fabiani A, Dreas L, Sanson G. Ultrasound-guided deep-arm veins insertion of long peripheral catheters in patients with difficult venous access after cardiac surgery. Heart Lung[Internet]. 2017[cited 2017 Jan 10];46(1):46-53. Available from: https://www.ncbi. nlm.nih.gov/pubmed/27780607

18. Melo EM, Aragão AL, Pessoa CMP, Lima FET, Barbosa IV, Studart RMB, et al. Care provided by nursing staff during the peripheral 
venipuncture procedure. Rev Enferm UFPE[Internet]. 2015[cited 2017 Jan 10];9(3):1022-30. Available from: https://periodicos. ufpe.br/revistas/revistaenfermagem/article/view/10430

19. Parker SI, Benzies KM, Hayden KA, Lang ES. Effectiveness of interventions for adult peripheral intravenous catheterization: a systematic review and meta-analysis of randomized controlled trials. Int Emerg Nurs[Internet]. 2016[cited 2017 Jan 10];31:15-21. Available from: https://www.ncbi.nlm.nih.gov/pubmed/27411965

20. Pereira KC, Cogo ALP, Silva APSS. Critical analysis of peripheral catheter venipuncture videos available on YouTube. Rev Min Enferm[Internet]. 2016[cited 2017 Jan 10];20:e970. Available from: http://www.reme.org.br/artigo/detalhes/1106

21. World Health Organization-WHO. World Alliance for Patient Safety[Internet]. 2004[cited 2017 Jan 10]. Available from: http:// www.who.int/patientsafety/worldalliance/en/

22. Brasil. Ministério da Saúde. Agência Nacional de Vigilância Sanitária. Documento de referência para o Programa Nacional de Segurança do Paciente. Brasília: Ministério da Saúde; 2014.

23. Danski MTR, Johann DA, Vayego SA, Oliveira GRL, Lind J. Complications related to the use of peripheral venous catheters: a randomized clinical trial. Acta Paul Enferm[Internet]. 2016[cited 2017 Jan 10];29(1):84-92. Available from: http://www.scielo.br/ pdf/ape/v29n1/en_1982-0194-ape-29-01-0084.pdf 